\title{
Symptomatic and Nonamyloid/Tau Based Pharmacologic Treatment for Alzheimer Disease
}

\author{
Paul S. Aisen ${ }^{1}$, Jeffrey Cummings ${ }^{2}$, and Lon S. Schneider ${ }^{3}$ \\ ${ }^{1}$ University of California, San Diego, California 92093 \\ ${ }^{2}$ Cleveland Clinic, Cleveland, Ohio 44195 \\ ${ }^{3}$ University of Southern California, Los Angeles, California 90007 \\ Correspondence: paisen@ucsd.edu
}

In this work we consider marketed drugs for Alzheimer disease (AD) including acetylcholinesterase inhibitors (AChE-ls) and antiglutamatergic treatment involving the $\mathrm{N}$-methylD-aspartate (NMDA) receptor. We discuss medications and substances available for use as cognitive enhancers that are not approved for AD or cognitive impairment, and other neurotransmitter-related therapies in development or currently being researched. We also review putative therapies that aim to slow disease progression by mechanisms not directly related to amyloid or tau.

\section{REGULATORY LANDSCAPE AND CLINICAL TRIALS}

North American and European Union regulatory criteria for marketing approval of putative symptomatic and disease-modifying therapeutic agents for Alzheimer disease (AD) are based on a demonstration of efficacy supported by improvements compared to placebo treatment on cognitive function, activities of daily living (ADL), and often evidence of overall clinical improvement or less overall decline, accompanied by adequate evidence of safety (Schneider 2008b). In practice this has led to rather standardized protocols by sponsors of experimental drugs. For example, mild to moderate AD is indexed by a MiniMental State Examination (MMSE) score of 10-26 and standardized outcomes including the Alzheimer's Disease Assessment ScaleCognitive Portion (ADAS-cog), the Alzheimer's Disease Cooperative Study Activities of Daily Living (ADCS-ADL) scale, or the Disability Assessment for Dementia (DAD). A clinician's global assessment (known as a Clinician Interview Based Impression of Change with caregiver input $[\mathrm{CIBIC}+]$ or ADCS Clinical Global Impression of Change [CGIC]) or the Clinical Dementia Rating (CDR), an interview-based overall dementia severity assessment, are the conventional outcomes measures. The trials are commonly 6-18 months in duration: 6 months for symptomatic and 12-18 months for disease-modifying trials. There is a current trend to include more mild patients with $\mathrm{AD}$, operationalized as MMSE greater than 20, amnestic mild cognitive impairment (MCI), or $\mathrm{MCI}$ due to $\mathrm{AD}$, prodromal or early $\mathrm{AD}$

Editors: Dennis J. Selkoe, Eckhard Mandelkow, and David M. Holtzman

Additional Perspectives on The Biology of Alzheimer Disease available at www.perspectivesinmedicine.org

Copyright (C) 2012 Cold Spring Harbor Laboratory Press; all rights reserved; doi: 10.1101/cshperspect.a006395

Cite this article as Cold Spring Harb Perspect Med 2012;2:a006395 
P.S. Aisen et al.

(supported by a positive cerebrospinal fluid [CSF] or imaging biomarker) (Schneider 2008b; Albert et al. 2011).

Five cholinesterase inhibitors, memantine, the Ginkgo biloba extract EGb 761, and cerebrolysin have some level of marketing approval for the treatment of $\mathrm{AD}$ in the Western hemisphere, Europe, Australia/New Zealand, Japan, and many Asian countries. One antipsychotic, risperidone, is specifically approved in several countries, e.g., UK, Spain, and Canada for the treatment of agitation, psychosis, or the behavioral and psychological symptoms of dementia (BPSD) occurring in AD.

\section{Considering Mechanisms of Action}

Demonstration of a mechanism, pharmacodynamic effect, or target engagement either in preclinical in vitro or in animal models, or in humans does not establish the relevance of the mechanism to the effect the drug might have on clinical manifestations. Many agents, including various antioxidant and so-called antiaging cocktails, are marketed based on the chemical properties of ingredients rather than randomized controlled trials of safety and efficacy. Such products may not have established safety, and certainly have no evidence of efficacy. Moreover, most drug products have multiple actions. Thus, with the few exceptions of drugs and antibodies that clearly engage only one target, characterizing a particular drug as having a certain mechanism of action may be misleading; yet this is often done as a matter of convenience or for categorization.

\section{ACETYLCHOLINESTERASE INHIBITORS}

Acetylcholinesterase inhibitors (AChE-Is) are the first class of agents specifically approved by the US Food and Drug Administration (FDA) for the treatment of $\mathrm{AD}$ (Fig. 1). Tacrine (Cognex) was approved in 1993 followed by approval of donepezil (Aricept) in 1996, rivastigmine (Exelon) in 2000, and galantamine (Reminyl, Razadyne) in 2001. Memantine (Namenda)-an NMDA receptor antagonist-approval followed in 2004 (Fig. 1). Tacrine had a short half-life requiring administration every 4 hours and had substantial associated hepatotoxicity, requiring frequent monitoring of liver enzymes. These limitations were not present with later AChE-Is. Tacrine is rarely used, is no longer available in many countries, and will not be discussed here.

All AChE-Is share the characteristic of inhibiting acetylcholinesterase and each of these agents has additional distinctive pharmacologic aspects. AChE-Is are thought to bind acetylcholinesterase in the synaptic cleft so that acetylcholine released from the presynaptic cholinergic terminal has an increased residence time within the synapse and is more likely to interact with the postsynaptic cholinergic receptor. The enhanced postsynaptic activity renders more normal the function of the cholinergic system.

Donepezil is a selective AChE-I, rivastigmine is a mixed acetylcholinesterase and butyrylcholinesterase inhibitor, and galantamine is described as having an allosteric nicotinic modulating effect as well as being an AChE-I. The clinical consequences of the differential pharmacology of the AChE-Is, if any, are unknown.

For purposes of drug development, patients were identified for AChE-I clinical trials as having mild to moderate AD by requiring a MMSE (Folstein et al. 1975) score between ten and 26 in most trials. All AChE-Is are approved for treatment of mild to moderate AD. In the clinical development of donepezil, trials of patients with moderate to severe $\mathrm{AD}$ were conducted and established efficacy of this agent in patients with MMSE scores of $0-15$. Donepezil is approved for mild, moderate, and severe $\mathrm{AD}$.

To meet the criteria for approval by the FDA as a treatment for $\mathrm{AD}$, an agent must be shown in two well-conducted trials to be statistically significantly superior to placebo on a test of cognition (regarded as the central feature of $\mathrm{AD}$ ) and a global scale or an assessment of ADL (Schneider 2008) The usual measure of cognition in mild to moderate AD is the ADASCog (Rosen et al. 1984). In patients with moderate to severe $\mathrm{AD}$ the cognitive measure most 


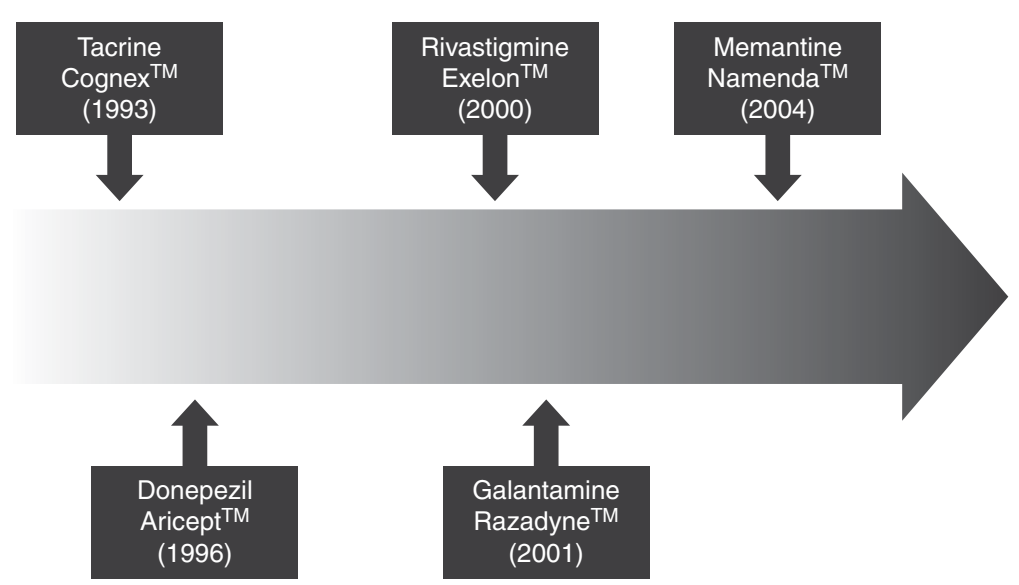

Figure 1. Timeline of approved treatments for Alzheimer disease.

commonly used is the Severe Impairment Battery (SIB) (Schmitt et al. 1997). The global outcome used in most AChE-I trials is the CIBIC+ (Schneider et al. 1997). ADL scales used in AChE-I trials include the ADCS ADL scale (Galasko et al. 1997) or the DAD (Gelinas et al. 1999). Changes in behavior are commonly measured as secondary outcomes in AChE-I clinical trials, and the most commonly used instrument is the Neuropsychiatric Inventory (NPI) (Cummings et al. 1994). Pharmacoeconomic data are collected in some trials using the Resource Utilization in Dementia (RUD) scale (Wimo and Winblad 2003). Most clinical trials of AChE-Is have been 6 months in duration; some have been as short as 3 months and some as long as 2 years (AD2000 Collaborative Group 2004).

The responses to treatment with different AChE-Is have overlapping confidence intervals (CI), and no individual cholinesterase inhibitor has been shown to be superior to others in terms of efficacy. The mean response on the ADAS-cog is approximately 2.0 points with CI of 1.5-2.5 points (Birks 2006). The response on the CIBIC + is usually in the range of 1.9 (CI 1.3-3.0) on a scale in which 4 represents no change. 3, 2 and 1 represent mild, moderate and marked improvement, and 5, 6, and 7 represent mild, moderate, and marked worsening (Whitehead et al. 2004). A two-point (CI 0.5-
2.5) drug-placebo difference is common at trial conclusion on the ADCS ADL and a two-point (CI 0.5-4.0) drug-placebo difference on the NPI total score is common at trial conclusion. Approximately 25\% of patients have a measurable improvement on the ADAS-Cog compared to $15 \%$ of patients on placebo. In addition to the drug-placebo difference in improvement, AChE-Is produce a delay in decline that affects as many as $80 \%$ of patients participating in a clinical trial (Geldmacher et al. 2006). Improvement on the ADAS-Cog is taken as an indication of improvement in the core clinical features of $\mathrm{AD}$, whereas a drug-placebo difference in CIBIC+ or an ADL scale is accepted as a measure of clinically meaningful improvement. As noted, most clinical trials of AChE-Is are 6 months in duration and establish benefit for 6 months of therapy; some 1-year trials (Winblad et al. 2001) or 2-year trials (AD2000 Collaborative Group 2004) have been conducted and continued to show a drug-placebo difference at study conclusion. These observations support the long-term use of AChE-Is in the treatment of $\mathrm{AD}$.

$\mathrm{AD}$ dementia is preceded by a period of cognitive impairment in which patients show decline in episodic memory and other cognitive abilities, but the changes are not sufficiently severe to reach the criteria for dementia. This clinical syndrome has been called mild 
P.S. Aisen et al.

cognitive impairment (MCI) (Petersen et al. 2001). Clinical trials of AChE-Is for the treatment of cognitive deficits of MCI have been uniformly negative (Jelic et al. 2006). It is now recognized that MCI is an etiologically heterogeneous state with only approximately 60$70 \%$ of patients having underlying $\mathrm{AD}$ (Jicha et al. 2006). The lack of response to AChE-Is in MCI may reflect the absence of an AD-type pathophysiology in a substantial number of patients included in the trial. In the ADCS MCI study, there was a drug-placebo benefit in favor of donepezil in MCI patients who were apolipoprotein E4 carriers, a group likely to have a high underlying rate of $\mathrm{AD}$ pathophysiology (Petersen et al. 2001). This suggests that prodromal $\mathrm{AD}$ may respond to treatment by AChE-Is. However, many of the patients enrolled in MCI trials could also have fulfilled criteria for AD.

Gastrointestinal side effects are common in patients placed on AChE-Is. Anorexia, nausea, vomiting, diarrhea, and weight loss may occur and should be monitored in patients treated with these agents. In addition, cholinergic influences may slow heart rate and bradycardia is a contraindication to use of AChE-Is. Occasional patients have experienced changes in urinary function. Muscle cramps have been reported with donepezil and abnormalities in dreaming also have been reported with donepezil.

In addition to the use of AChE-Is in $\mathrm{AD}$, rivastigmine has been approved by the FDA for treatment of mild to moderate Parkinson's disease dementia (Emre et al. 2004). AChE-Is have also been assessed in clinical trials of vascular dementia (Black et al. 2003; Kavirajan and Schneider 2007), mixed AD and cerebrovascular disease (Erkinjuntti et al. 2002), and dementia with Lewy bodies (McKeith et al. 2000). None of these indications has been approved by the FDA and use of AChE-Is in these settings is off label.

Donepezil has a half-life of 70 hours and is administered once daily (Table 1). It is 96\% protein bound with $100 \%$ bioavailability; it is metabolized by 2D6 and 3A4 cytochrome P450 enzymes. Treatment is begun with $5 \mathrm{mg} /$ day and, if the patient shows no intolerance, the dose is advanced to $10 \mathrm{mg}$ /day usually after 1 month. A $23 \mathrm{mg}$ once-daily dose has recently been approved for use in patients with moderate to severe AD (Okamura et al. 2008). Acetylcholinesterase positron emission tomography (PET) studies suggest that the $10 \mathrm{mg}$ dose produces an approximately $60 \%$ inhibition of central acetylcholinesterase (Okamura et al. 2008). Rivastigmine has a peripheral half-life of 1.5 hours and a central half-life of 8 hours. The capsules are given twice daily and, when administered as the patch formulation, the patch is replaced once daily. Rivastigmine is not metabolized through the cytochrome P450 system; it is $40 \%$ protein bound and has $40 \%$ bioavailability. Rivastigmine is initiated in an oral dose of $1.5 \mathrm{mg}$ orally twice daily and, as tolerance is determined, advanced to $3 \mathrm{mg}, 4.5 \mathrm{mg}$, and $6 \mathrm{mg}$ twice daily for a total target dose of $12 \mathrm{mg} /$ day. Titration is typically at 1-month intervals and is determined by patient tolerance for the agent. The transdermal patch formulation of rivastigmine is initiated at a patch strength of $4.6 \mathrm{mg}$ and advanced to $9.5 \mathrm{mg}$ after 1 month if no intolerance is observed. Galantamine has a half-life of 7 hours and is given twice daily, unless the extended release formulation is used and administered once daily. Galantamine is initiated at a dose of $4 \mathrm{mg}$ twice daily $(8 \mathrm{mg} /$ day in a single dose for the extended release formulation) and advanced to 16 and $24 \mathrm{mg} /$ day at 1-month intervals. Galantamine is metabolized by the cytochrome P450 enzymes 2D6 and 3A4. It is 18\% protein and has $90 \%$ bioavailability.

There are conflicting data as to whether AChE-Is have any disease-modifying properties with respect to $\mathrm{AD}$. They affect disease course by improving symptoms and delaying decline as described above. Basic science observations suggest that enhancement of cholinergic function may reduce the generation of $\beta$-amyloid protein (Kimura et al. 2005). Some imaging studies have suggested less brain atrophy over time in patients treated with AChE-Is (Krishnan et al. 2003). In addition, some long-term observations suggest less decline in patients treated with AChE-Is or combination therapy of AChE-Is with memantine compared to 
Symptomatic and Other Treatments for Alzheimer Disease

Table 1. Characteristics of cholinesterase inhibitors

\begin{tabular}{|c|c|c|c|}
\hline \multirow[b]{2}{*}{ Characteristic } & \multicolumn{3}{|c|}{ Cholinesterase inhibitors } \\
\hline & Donepezil & Rivastigmine & Galantamine \\
\hline Trade name & $\begin{array}{l}\text { Aricept (Aricet in } \\
\text { some countries) }\end{array}$ & Exelon & Razadyne and Razadyne-ER \\
\hline Indications & $\begin{array}{l}\text { Mild to moderate } \\
\text { and severe } \mathrm{AD}\end{array}$ & $\begin{array}{l}\text { Mild to moderate AD; } \\
\text { Parkinson's disease dementia }\end{array}$ & Mild to moderate $\mathrm{AD}$ \\
\hline Half-life & 70 hours & $\begin{array}{l}1.5 \text { hours (brain half-life is } \\
8 \text { hours) }\end{array}$ & 7 hours \\
\hline $\begin{array}{l}\text { Administration } \\
\text { schedule }\end{array}$ & q.d. & $\begin{array}{l}\text { b.i.d. for capsules; q.d. for the } \\
\text { patch }\end{array}$ & $\begin{array}{l}\text { b.i.d. for the non-ER form: q.d. } \\
\text { for the ER form }\end{array}$ \\
\hline $\begin{array}{l}\text { Metabolism by } \\
\text { hepatic CYP } \\
\text { enzymes }\end{array}$ & 2D6, 3A4 & No & 2D6, 3A4 \\
\hline Protein binding & $96 \%$ & $40 \%$ & $18 \%$ \\
\hline Bioavailability & $100 \%$ & $40 \%$ & $90 \%$ \\
\hline $\begin{array}{l}\text { Time to peak } \\
\text { serum level }\end{array}$ & $3-4$ hours & 1 hour & $\begin{array}{l}1 \text { hour ( } 2.5 \text { hours with food }) ; 4.5 \\
\text { hours for ER form }\end{array}$ \\
\hline $\begin{array}{l}\text { Absorption delayed } \\
\text { by food }\end{array}$ & No & No & Yes ( 1 hour to 2.5 hours) \\
\hline Titration & $\begin{array}{l}\text { Begin with } 5 \mathrm{mg} \\
\text { and advance to } \\
10 \mathrm{mg} \text { after } 1 \\
\text { month }\end{array}$ & $\begin{array}{l}\text { Oral form: } 1.5 \mathrm{mg} \text { b.i.d. for } 4 \\
\text { weeks; } 3 \mathrm{mg} \text { b.i.d. for } 4 \text { weeks; } \\
4.5 \mathrm{mg} \text { b.i.d. for } 4 \text { weeks; } \\
\text { advance to } 6 \mathrm{mg} \text { b.i.d. if } \\
\text { tolerated } \\
\text { Patch form: begin the } 5 \mathrm{~cm}^{2} \\
\text { patch for } 1 \text { month then } \\
\text { advance to } 10 \mathrm{~cm}^{2} \text { patch }\end{array}$ & $\begin{array}{l}\text { Non-ER form: begin } 4 \mathrm{mg} \text { b.i.d.; } \\
\text { advance to } 8 \mathrm{mg} \text { b.i.d. after } 1 \\
\text { month and to } 12 \mathrm{mg} \text { b.i.d. } \\
\text { after } 1 \mathrm{month} \\
\text { ER form: begin at } 8 \mathrm{mg} \text { q.d.; } \\
\text { advance after } 1 \text { month to } \\
16 \mathrm{mg} \text { DQ and after } 1 \text { month } \\
\text { to } 24 \mathrm{mg} \text { q.d. }\end{array}$ \\
\hline
\end{tabular}

Tacrine (Cognex) is now rarely used because of associated liver enzyme elevations and is not included in this chart.

patients not receiving therapy with these agents (Lopez et al. 2009; Rountree et al. 2009). Other clinical and imaging studies, however, suggest no disease-modifying benefit from treatment with AChE-Is (Jack et al. 2008; Schneider and Sano 2009). Disease-modifying effects, if present, must be small in magnitude.

Patients intolerant to one AChE-I may be able to tolerate an alternate cholinesterase inhibitor and the effort to keep patients on therapy should be made when intolerance occurs. Patients started on an oral medication might be switched to patch therapy or vice versa. Patients showing no efficacy in response to treatment with one cholinesterase inhibitor (uninterrupted continuing decline of cognition) may also be switched to another. Any benefit from switching in this circumstance however is not established.
Continuing benefit from use of AChE-Is has been shown in trials lasting up to 2 years, among patients followed over that length of time (AD2000 Collaborative Group 2004). In addition, patients with severe $\mathrm{AD}$ - not previously treated with AChE-Is-respond to treatment with AChE-Is, and donepezil is approved for treatment in this advanced phase of the disease. These observations suggest that long-term treatment with AChE-Is may continue to provide benefit. When AChE-Is are discontinued because the patient or the clinician believe that no further benefit is possible, patients should be observed for cognitive decline, loss of ADL, or emergent behavioral disturbances (Holmes et al. 2004). If adverse cognitive, functional, or behavioral changes occur soon after discontinuation then physicians and patients should consider whether the patient had been 
P.S. Aisen et al.

benefiting from treatment and whether to reinitiate medications at the starting doses.

\section{MEMANTINE}

Memantine was used in Germany for the treatment of Parkinson's disease prior to its approval in the USA and globally for treatment of AD. A key 12-week clinical trial of memantine for patients with dementia, mainly $\mathrm{AD}$, residing in nursing homes was published in 1999 (Winblad and Poritis 1999) followed by publication of a monotherapy trial in 2000 (Reisberg et al. 2003a) and of a donepezil add-on trial in 2004 (Tariot et al. 2004). Memantine was approved by the FDA in the USA in 2004 for treatment of moderate to severe $\mathrm{AD}$, meaning patients with MMSE scores less than 15. Memantine is an NMDA receptor antagonist that replaces potassium in the NMDA receptor channel to reduce entry of calcium into neurons and avoid calcium-stimulated apoptotic cell death cascades. It is uncertain if the neuroprotective activities observed consistently in in vitro studies account for the symptomatic benefit observed in clinical trials. In vitro experimental studies suggest reduced $A \beta$ plaque deposition and reduced tau hyperphosphorylation following treatment with memantine (MartinezCoria et al. 2010). Physiological studies establish a beneficial effect for long-term potentiation (LTP), the physiological correlate of memory (Frankiewicz and Parsons 1999). This latter observation provides a potential explanation for the symptomatic benefit observed with treatment with memantine.

Clinical trials of memantine have been very similar in design to those conducted with AChE-Is, but have involved patients with moderate to severe $\mathrm{AD}$, rather than mild to moderate AD. Trials have typically been 6 months in duration with the SIB, CIBIC+, or ADCS-ADL as primary outcomes and ADL or behavior as secondary outcomes. The magnitude of benefit from treatment with memantine is similar to the magnitude observed for AChE-Is. Two of three moderate to severe $\mathrm{AD}$ trials with memantine showed statistical significance on their primary outcomes (Reisberg et al. 2003b; van Dyck et al. 2007), including an add-on trial, in which patients on long-term treatment with donepezil, randomized to receive either placebo or add-on memantine, showed that add-on therapy with memantine produced a statistically significant benefit compared to add-on therapy with placebo (Tariot et al. 2004).

Several clinical trials have been conducted with memantine patients with mild to moderate $\mathrm{AD}$. One of these trials showed benefit on cognition, global assessment, and behavior (Peskind et al. 2006); two trials did not show significant drug-placebo differences (Bakchine and Loft 2008; Porsteinsson et al. 2008). Memantine is not approved by the FDA for patients with mild AD. European regulatory authorities extended the range of approval for use of memantine to patients with MMSE scores of 19 and below.

Memantine has a half-life of $60-80$ hours, is $50 \%$ protein bound, is not metabolized by the cytochrome P450 hepatic enzymes, and its absorption is not delayed by food (Table 2). Memantine is subject to renal excretion and the dose should be decreased by $50 \%$ in $\mathrm{AD}$ patients with renal failure. Memantine is initiated at a dose of $5 \mathrm{mg}$ per day for 1 week, it is then advanced to $5 \mathrm{mg}$ twice daily for 1 week; the next dose is $10 \mathrm{mg}$ in the morning and $5 \mathrm{mg}$ in the evening for 1 week; and the final dose is $10 \mathrm{mg}$ twice daily. This is the continuing permanent dose for patients who do not have evidence of intolerance. Adverse events reported with memantine therapy include headache, dizziness, and somnolence. There have been reports of confusion during the titration period and occasional reports of hallucinations.

Memantine is approved for moderate to severe $\mathrm{AD}$ and may be given either alone or in conjunction with an AChE-I. No adverse drug interactions have been reported with patients receiving AChE-Is plus memantine, and the drugs are safe when used together. Although some long-term open-label observations suggest that combination therapy with an ACHE-I and memantine may ameliorate the course of AD (Lopez et al. 2009; Rountree et al. 2009), other studies suggest otherwise (Schneider et al. 2011). Observations in the course of 
Table 2. Characteristics of memantine

\begin{tabular}{|c|c|}
\hline Trade name & Namenda (Ebixa or Axura in some countries) \\
\hline Indications & Moderate to severe AD (USA) up to MMSE scores of 20 in Europe and Asia \\
\hline Half-life & $60-80$ hours \\
\hline Protein binding & $50 \%$ \\
\hline $\begin{array}{l}\text { Metabolism by hepatic CYP } \\
\text { enzymes }\end{array}$ & No \\
\hline Absorption delayed by food & No \\
\hline Time to peak serum level & $3-7$ hours \\
\hline $\begin{array}{l}\text { Adjustment in hepatic or renal } \\
\text { disease }\end{array}$ & Decrease dose by $50 \%$ in patients with renal failure \\
\hline Titration & $\begin{array}{l}5 \text { q.d. for } 1 \text { week; } 5 \text { b.i.d. for } 1 \text { week; } 10 \mathrm{mg} \text { in a.m. and } 5 \mathrm{mg} \text { in p.m. for } 1 \text { week; } \\
10 \mathrm{mg} \text { b.i.d. thereafter }\end{array}$ \\
\hline
\end{tabular}

double-blind placebo-controlled trials suggested that patients on therapy decline at equal rates when compared to patients not receiving therapy (Schneider and Sano 2009).

Patients are usually treated with memantine or a combination of an ACHE-I plus memantine until late in the course of AD. Pharmacotherapy may be continued until the patients succumbs or until their physicians and family conclude that the quality of life of the patient is sufficiently compromised that pharmacotherapy is futile.

\section{Use of Psychotropic Agents to Treat Behavioral Disturbances in AD}

Behavioral disturbances are common in $\mathrm{AD}$, including depression, agitation, irritability, aberrant motor behaviors, and psychosis (Cummings 2003). There are no agents approved by the FDA specifically for treatment of behavioral disturbances in AD. Antipsychotics - both conventional and atypical-are associated with increased mortality and some antipsychotics are associated with increased risk for cerebrovascular accidents or stroke when administered to elderly patients with AD. The risk of death is increased from $\sim 2.6 \%$ to $\sim 4.5 \%$ during an average of 10 weeks of therapy. Long-term observations suggest that continuing therapy is associated with a continuing increased risk for mortality (Kales et al. 2007; Ballard et al. 2009). Several 1-12 week long clinical trials suggest that risperidone and possibly other atypical antipsychotic agents in low doses are efficacious in reducing psychosis and agitation in mainly nursing home patients with AD (Ballard and Waite 2006; Schneider et al. 2006). Given the evidence of benefit and harm for the use of antipsychotics in $\mathrm{AD}$, the clinician must exercise caution when prescribing these agents. Strategies for use of antipsychotics in patients with $\mathrm{AD}$ involve avoiding their use in patients with cardiovascular or pulmonary disease (the two most common causes of death in mortality studies), using these agents only in patients for whom nonpharmacologic interventions have failed and the behaviors are extreme, employing treatment for only the period required and attempting to eliminate the agents as soon as possible, and informing the patient and caregiver of the risks involved.

Clinical trials have been largely negative in showing benefit for treatment of depression in $\mathrm{AD}$ with antidepressant medications (Lyketsos et al. 2000; Olin et al. 2002; Rosenberg et al. 2010; Weintraub et al. 2010). There is no consistent evidence base for the use of antidepressants in $\mathrm{AD}$. Individual practitioners may use practice-based evidence to guide their therapeutic decisions. Several recent trials suggest that use of valproate to treat agitation has no superiority over placebo and is associated with substantial toxicity (Tariot et al. 2005; Herrmann et al. 2007). Early trials suggested the benefit of carbamazepine as a treatment for agitation (Tariot et al. 1998). Anxiolytics and 
P.S. Aisen et al.

hypnotics are generally to be avoided in patients with $\mathrm{AD}$ as they may increase confusion. Shortterm use of benzodiazepines such as lorazepam or clonazepam may be useful in patients with episodes of agitation.

There is an urgent need for effective, safe, psychotropic agents for treatment of behavioral disturbances in $\mathrm{AD}$ and other dementing disorders.

\section{OTHER TREATMENTS MARKETED FOR AD IN SOME COUNTRIES}

The following three substances are approved for use or widely used in some individual countries for cognitive impairment syndromes but are not FDA or EMA approved.

\section{Ginkgo Biloba}

Ginkgo biloba leaves and extracts are widely used in over-the-counter preparations marketed in the USA as food supplements or nutraceuticals and, as such, explicit health claims are not listed in their labeling (Schneider 2008a). In several countries $G$. biloba is advocated for the treatment of a broad range of medical conditions including, as examples, tinnitus and dizziness. The extract that is approved for use in some countries is Ginkgo biloba extract EGb 761 (Ipsen Pharma, and Schwabe Pharmaceuticals), standardized to contain two major constituents: $22-27 \%$ flavonoids and 5-7\% terpene lactones (ginkgolides and bilobalide).

The flavonoids are active as antioxidants and appear neuroprotective. Ginkgolide B is a potent antagonist of the platelet-activating factor receptor. Ginkgolides A and J variously inhibit hippocampal neuron dysfunction and neuronal cell death caused by amyloid- $\beta$ protein-42 (A $\beta 42)$. Ginkgolides A and J decrease A $\beta 42$-induced pathological behaviors, enhance neurogenesis in animal models of $\mathrm{AD}$, and inhibit $A \beta$ aggregation, providing considerable rationale for $G$. biloba extracts as potential treatments for AD.

Trials in older and younger adults who do not have cognitive impairment show mixed results at best (Schneider 2008a). One meta- analysis of eight trials did not find evidence for cognitive benefits with G. biloba in noncognitively impaired participants younger than 60 years treated for up to 13 weeks. Two placebocontrolled trials reported contradictory effects in noncognitively impaired older adults, and the magnitude of the cognitive effects were small in the positive trial.

A systematic review that included 35 clinical trials and 4247 participants reported inconsistent evidence that G. biloba had clinically significant benefits for dementia or cognitive impairment (Birks and Grimley Evans 2009). One 6-month trial in mild to moderate $\mathrm{AD}$ sponsored by Schwabe Pharmaceuticals, conducted with the hope of gaining US FDA marketing approval, failed to demonstrate efficacy (Schneider et al. 2005), as did another 6-month trial performed at British primary care sites with $120 \mathrm{mg}$ /day doses of EGb 761 (McCarney et al. 2008).

Perhaps because of its popularity and perceived safety there have been three prevention trials undertaken using EGb 761 at $240 \mathrm{mg}$ daily doses. A trial involving 118 participants without MCI or dementia, all older than 85 years, randomized to receive G. biloba extract or placebo and followed up for 42 months, showed a nonsignificant effect for G. biloba to delay progression to MCI (Dodge et al. 2008). Of potential concern, however, was that more ischemic strokes and transient ischemic episodes occurred in the G. biloba group. The GEM trial randomized 3069 persons to $G$. biloba extract or placebo who had no cognitive impairment or MCI for a median duration of more than 6 years and found no clinical effects for the extract on cognition or time to dementia (DeKosky et al. 2008). A second prevention trial, GuidAge, conducted in France and involving 2854 participants with memory complaints or MCI, randomized to G. biloba or placebo and followed for more than 5 years, also failed to find effects for ginkgo on the primary outcome of time to onset of $\mathrm{AD}$ or other dementia (Ipsen press release, 22 June 2010). Thus, there is very little evidence for the efficacy of $G$. biloba either for improving symptoms or preventing AD. 


\section{Cerebrolysin}

Cerebrolysin is a somewhat controversial approach to neurotrophic therapy for $\mathrm{AD}$. This product is a parenterally administered digested peptide preparation derived from pig brain. In vitro studies suggest that this peptide mixture has neuroprotective effects. There is some evidence of brain penetration with peripheral administration. There have been a number of clinical studies of Cerebrolysin infusion therapy in $\mathrm{AD}$, with some results suggesting symptomatic benefit (Okamura et al. 2008). As a result, it has being widely used in many countries. Skepticism arises from the poorly defined composition and mechanisms and inconsistencies in clinical findings, but some have called for more definitive trials.

\section{Huperzine A}

Huperzine A is a plant extract with potent, selective AchE1 inhibition used in China for the treatment of dementia. Preclinical studies suggest possible neuroprotective mechanisms. A recent Phase II trial in the USA failed to demonstrate efficacy of the usual dose used in China, 200 mcg twice daily, but did provide some evidence of cognitive enhancement at twice this dose (Rafii et al. 2011).

\section{DIETARY SUPPLEMENTS, VITAMINS, NUTRICEUTICALS, MEDICAL FOODS}

A dietary supplement is defined by US law as a product (other than tobacco) that is intended to supplement the diet; contains one or more dietary ingredients (including vitamins, minerals, herbs or other botanicals, amino acids, and other substances) or their constituents; is intended to be taken by mouth; and is labeled on the front panel as being a dietary supplement (United States Dietary Supplement Health and Education Act of 1994 (http://www.fda.gov/ opacom/laws/dshea.html\#sec3).

The word nutraceutical has no official meaning, but was coined to imply nontraditional products with pharmaceutical effects. A dietary supplement promoter cannot make a healthdisease treatment claim for the substance.
Thus, for example, a supplement could be advertised as enhancing "brain power," brain cells or concentration, but not as a treatment for $\mathrm{AD}$ or attention deficit disorder, as the latter are health claims.

Several dietary supplements and vitamins have been used in clinical trials for $\mathrm{AD}$, cognitive impairment, or age associated memory impairment (AAMI; older individuals who have cognitive test scores below the norms for young adults) and have been indirectly promoted by various interest groups as treatments for AD. Formulations of these substances vary, with no regulatory standard except that products must contain the substance advertised.

\section{Docosahexaenoic Acid}

Docosahexaenoic acid (DHA) is the primary constituent of membranes in the central nervous system (CNS). DHA levels in brain decline with age, but can be restored with dietary supplementation. Adding DHA to the diet of transgenic mice with amyloid deposition in brain reduces amyloid accumulation and improves cognitive performance. There is thus a reasonable rationale for studying DHA supplementation as a therapeutic intervention for cognitive aging and AD.

One trial conducted by a manufacturer of DHA, Martek, in individuals with AAMI did not yield significant results. Post-hoc analyses suggest possible benefits in measures of episodic memory (Okamura et al. 2008).

An NIA-funded trial of DHA for mild to moderate $\mathrm{AD}$ was, however, negative (Quinn et al. 2010). Treatment with DHA for 18 months increased CSF levels (in the subset who underwent lumbar punctures), but did not alter the decline in cognitive and functional assessments.

\section{B Vitamins}

Elevated homocysteine in blood is considered a risk factor for cardiovascular disease, vascular dementia, and AD. Plasma concentrations increase when homocysteine's metabolism to methionine or cysteine is impaired, which may 
P.S. Aisen et al.

occur under a number of circumstances, including natural aging. Increased blood levels of homocysteine are associated with damage to vascular endothelial cells through lipid peroxidation and release of endothelium-derived relaxing factor, and may increase the risk of vascular thrombosis. More relevant to AD, homocysteine potentiates the neurotoxic effects of $\beta$-amyloid peptides in vitro. Homocysteine plasma levels can be reduced by as much as $30 \%$ using regimens of B vitamins (e.g., B12 $1 \mathrm{mg} /$ day, B6 $25 \mathrm{mg} /$ day, and folic acid $5 \mathrm{mg} /$ day). A placebo-controlled clinical trial of these vitamins over 18 months confirmed that substantial reduction in homocysteine could be achieved but did not slow the rate of cognitive decline in $\mathrm{AD}$ compared to placebo (Aisen et al. 2008; Okamura et al. 2008). A study of a similar regimen in individuals with MCI showed reduction of whole brain atrophy with vitamin use for 2 years (Smith et al. 2010). A fixed combination of B6, B12, and folate known as Cerefolin is marketed as a medical food (see below) for treatment of metabolic abnormalities associated with AD.

\section{Vitamin E}

The antioxidant effects of vitamin E (DL- $\alpha$ tocopherol) might have an impact on reducing clinical progression. In the prototypical antioxidant trial, vitamin E (1000 IU twice a day) and selegiline ( $5 \mathrm{mg}$ twice a day), each given alone to moderately impaired patients with AD, delayed the time until patients required nursing home placement, died, or lost ADL (Sano et al. 1997).

Overall, the delayed time to these end points was approximately 7 months compared to placebo. There were no effects on cognition in this group of patients, who were more severely impaired than in many other studies. Adverse effects included falls and syncope in selegiline patients ( 9 and 10\%, respectively), $\alpha$-tocopherol patients (14 and 7\%, respectively), and the combination (22 and 16\%, respectively).

A multicenter trial in MCI patients reported no significant delay in conversion to $\mathrm{AD}$ or dementia in cognitive effects with $\alpha$-tocopherol (or donepezil) over 3 years of treatment
(Petersen et al. 2005). Taken together, considering the absence of cognitive efficacy and the potential risks for treatment, vitamin E cannot be recommended as treatment.

\section{Homotaurine}

Originally synthesized and manufactured as a drug in development for $\mathrm{AD}$ under the name tramiprosate (3-amino-1-propanesulfonic acid) and the trade name Alzhemed, the amino acid homotaurine is now sold in Canada as a nutraceutical under the brand name Vivimind. The rationale for this is that, although the product is synthesized, homotaurine is also a natural component of certain seaweeds.

The rationale for its development as a prescription drug for $\mathrm{AD}$ was as an $\mathrm{A} \beta$ aggregation inhibitor. After a Phase II safety study in which CSF A $\beta$ was decreased (Aisen et al. 2006), two 18-month Phase III trials (one of which was stopped early) did not show efficacy. The company currently advances its use without a specific health claim as a food supplement.

\section{MEDICAL FOODS}

A medical food is "a food which is formulated to be consumed or administered enterally (or orally) under the supervision of a physician, and which is intended for the specific dietary management of a disease or condition for which distinctive nutritional requirements, based on recognized scientific principles, are established by medical evaluation," under the Orphan Drug Amendments of 1988 and the Nutrition Labeling and Education Act of 1990 (see 21 U.S.C. sec. 360ee(b)(3), 21 C.F.R. sec. 101.9(j)(8), and "Guidance for Industry: Frequently Asked Questions About Medical Foods" (May 2007), FDA website).

In addition, the contents of a medical food must fulfill the Generally Recognized as Safe (GRAS) designation for foods.

\section{Axona (Ketasyn; AC-1202)}

A mixture of medium-chain triglycerides, brand named Axona, was marketed in March 2009 as a medical food for AD. The rationale 
Symptomatic and Other Treatments for Alzheimer Disease

is that $\mathrm{AD}$ or other cognitive impairment may be partly a consequence of impaired glucose metabolism (see below), and that this can be treated by using medium-chain triglycerides that are converted to ketones, raising ketone levels, which enhance mitochondrial electron transport that otherwise was impaired by the impaired glucose metabolism (Henderson et al. 2009). Separately, some studies show that a ketogenic diet reduces $A \beta 40$ and 42 in transgenic mice.

In two 12-week placebo-controlled randomized trials for $\mathrm{AD}$ and AAMI there was no statistical evidence for cognitive or behavioral effects (Henderson et al. 2009). In the trial with $152 \mathrm{AD}$ patients significant improvements on the ADAScog were noted at 6 weeks but not at 12 weeks, and post hoc the very few APOE4negative patients in the trial seemed to improve at 12 weeks (Henderson et al. 2009). The 159-patient trial with AAMI patients was also not significant, showing two of the memory subscales to be significant in post hoc analyses.

\section{Souvenaid}

Another company, Danone, is developing and testing in clinical trials a brand name medical food, Souvenaid, that is comprised of a combination of food supplements, including uridine monophosphate, choline, omega-3 fatty acids (EPA, DHA), phospholipids, B vitamins, and antioxidants (Scheltens et al. 2010). The rationale is that this specific combination might synergistically enhance dendritic spine growth, synapse formation, neurotransmitter precursors, and neurotransmitter release, ultimately improving cognitive function. The company also claims the combination reduced amyloid production and toxicity in the preclinical models. Results of a 12-week, placebo-controlled trial in 225 patients with AD were nonsignificant on most of the outcomes (Scheltens et al. 2010). There are ongoing, longer, and larger trials in the USA and Europe.

Thus, there is no evidence for efficacy for these two medical foods and more studies are needed.

\section{OTHER NEUROTRANSMITTER-BASED TREATMENTS}

\section{Cholinergic Agonists}

A range of $\mathrm{M} 1$, muscarinic agonists with variable specificity for the $\mathrm{M} 1$ receptor subtype have been tested in 6-month symptomatic trials. Although some have shown distinct cognitive signals on standard clinical trials outcomes, they also produce considerable and troublesome cholinergic adverse effects such as gastrointestinal disturbances, diaphoresis, syncope, and hypersalivation. The M1 agonists also show salutary effects on $\mathrm{A} \beta$ in preclinical models. There have been no trials of lower doses over longer time periods to assess the potential for disease modification.

\section{Neuronal Nicotinic Receptor Agonists}

Neuronal nicotinic acetylcholine receptors (NNRs) are widespread throughout the central and peripheral nervous system. They mediate aspects of memory, attention, arousal, mood, anxiety, and sensory perception. NNR agonists can affect acetylcholine receptors through full and partial agonism or positive allosteric modulation. Receptor stimulation may increase release of several neurotransmitters implicated in CNS disorders including dopamine, serotonin, glycine, glutamate, and GABA. There may be a physiological inverted dose-response where low doses of NNR agonists enhance cognition and higher doses do not.

Two classes of NNRs may be involved in CNS disorders: (1) $\alpha 7$, and (2) $\alpha 4 / \beta 2$, and serve as targets. The $\alpha 7$ agonists predominate in areas more directly linked to memory and may also serve a neuroprotective function by reducing oxygen free radicals and nitric oxide. An $\alpha 7$ agonist in particular could be expected to be both symptomatic and have disease modifying properties as it enhances cognitive performance in behavioral models that capture domains of working memory, recognition memory, memory consolidation, and sensory gating deficit, increases the release of both presynaptic and postsynaptic calcium, and increases the release of Ach, glutamate, serotonin, and dopamine. 
P.S. Aisen et al.

\section{PDE Inhibition}

A rational behind phosphdiesterase 4 (PDE4) inhibition is that it leads to CREB up-regulation, which should promote neurotrophin expression, and thus may have both cognition enhancing and neuroprotective effects. The molecules in development so far have not succeeded, having manifested significant cardiac and gastrointestinal adverse effects.

EHT0202 (etazolate $\mathrm{HCl}$ ) shows both potential symptomatic and disease-modifying effects in $\mathrm{AD}$, acting as a PDE-4 inhibitor and GABA-A receptor modulator, increasing $\alpha$-secretase activity and sAPP $\alpha$ secretion, thus lowering $A \beta$. PDE inhibitors involving a variety of PDE enzymes are being tested in early-phase AD trials (Okamura et al. 2008).

\section{AMPA Receptor Modulation}

More challenging, in terms of safety, is the work being done on neurotrophically highimpact AMPA modulators. Lilly's high-impact LY451395 failed in an AD Phase II trial, but this trial used tiny doses $(0.2 \mathrm{mg}$ for 28 days, then $1.0 \mathrm{mg}$ thereafter) which speaks to the low therapeutic index, probably related to seizure risk. Cortex believes they have achieved the necessary balance between trophic effect and seizure risk with CX-1837, but have not completed that molecule's preclinical testing.

\section{H3 Antagonists}

The $\mathrm{H} 3$ receptor has the highest affinity for histamine among the four histamine receptors and is predominantly expressed in the cerebral cortex, hippocampus, and hypothalamus in which it functions as a presynaptic autoreceptor to regulate histamine release and cholinergic and monoaminergic neurotransmitter release. $\mathrm{H} 3$ blockage results in the release of neurotransmitters and is associated with enhanced cognitive function in preclinical models. Several H3 receptor agonists are in early stage clinical trials for treatment of the cognitive or motivational aspects of $\mathrm{AD}$.

\section{OTHER APPROACHES TO AD TREATMENT}

There are many drug development programs pursuing strategies not directly related to amyloid, tau, or neurotransmission. As discussed above, the putative mechanisms may be impossible to specify and may be multiple; there is generally no way to connect drug activity in experimental symptoms specific to clinical results in the management of $\mathrm{AD}$. Many such agents are listed in Table 3, and examples are discussed below.

\section{DRUGS WITH METABOLIC ACTIONS}

There is evidence that diabetes may increase the risk of $\mathrm{AD}$, and a variety of animal and human studies support the concept that insulin resistance in brain may play a role in $\mathrm{AD}$ (Craft 2007). Increasing attention is being paid to the possible interrelationship between $\mathrm{AD}$ and diabetes as epidemiologic studies suggest that people with Type 2 diabetes mellitus are twice as likely to develop $\mathrm{AD}$ as nondiabetics. Insulin may prevent the soluble toxic form of $A \beta$ from damaging neurons. Insulin protection was enhanced by the presence of rosiglitazone. Intranasal or IV insulin has been shown to improve cognitive performance in small studies of individuals with AD. Additional studies of insulin therapy are planned.

\section{PPAR $\gamma$-Agonists}

The peroxisome proliferator activated receptor $\gamma(\operatorname{PPAR} \gamma)$ is activated by a variety of fatty acids and fatty acid derivatives, and regulates adipocyte differentiation and function. PPAR $\gamma$ agonists such as rosiglitazone (Avandia) and pioglitazone (Actos) further mediate insulin actions and are marketed drugs for diabetes. They also may have actions relevant to $\mathrm{AD}$, including anti-inflammatory effects. However, a study of a pioglitazone found mixed results, with no difference on most cognitive measures (Sato et al. 2009; Geldmacher et al. 2011). Six- and 12-month Phase III trials of rosiglitazone, a PPARy agonist also targeting insulin resistance and related pathways failed to 


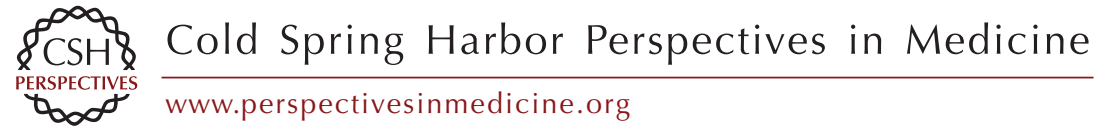

Table 3. Selected drug development programs

\begin{tabular}{|c|c|c|c|c|c|c|}
\hline Name & Sponsor & $\begin{array}{l}\text { Proposed mechanism or } \\
\text { therapeutic rationale }\end{array}$ & $\begin{array}{c}\text { Target } \\
\text { population }\end{array}$ & Supportive studies & $\begin{array}{l}\text { Nonsupportive } \\
\text { studies/issues }\end{array}$ & Current status \\
\hline Insulin & NIA & $\begin{array}{l}\text { Correction of insulin } \\
\text { abnormalities that may } \\
\text { contribute to pathology and } \\
\text { synaptic dysfunction }\end{array}$ & $\mathrm{MCI}, \mathrm{AD}$ & $\begin{array}{l}\text { Small Phase II RCTs with } \\
\text { some positive effects } \\
\text { (Craft et al. 2011) }\end{array}$ & & $\begin{array}{l}\text { Additional Phase II } \\
\text { trials planned }\end{array}$ \\
\hline Rosiglitazone & GSK & $\begin{array}{l}\text { Anti-inflammatory effect; } \\
\text { improve brain insulin resistance }\end{array}$ & $\mathrm{AD}$ & $\begin{array}{l}\text { Exploratory Phase II } \\
\text { analyses (Risner } \\
\text { et al. 2006) }\end{array}$ & Phase III & Not actively pursued \\
\hline Dimebon & $\begin{array}{l}\text { Medivation/ } \\
\text { Pfizer }\end{array}$ & Mitochondrial neuroprotectant & $\mathrm{AD}, \mathrm{HD}$ & $\begin{array}{l}\text { Phase II (Doody } \\
\text { et al. 2008) }\end{array}$ & $\begin{array}{l}\text { Phase III } \\
\text { monotherapy }\end{array}$ & $\begin{array}{l}\text { Phase III add-on } \\
\text { study in progress }\end{array}$ \\
\hline DHA & NIA, Martek & Restore membrane function & $\mathrm{AD}, \mathrm{AAMI}$ & $\begin{array}{l}\text { Epidemiology plus } \\
\text { post-hoc analyses in } \\
\text { cognitive aging trial }\end{array}$ & ADCS trial in $\mathrm{AD}$ & $\begin{array}{l}\text { Additional studies in } \\
\text { genetic subgroups } \\
\text { and/or MCI are } \\
\text { under discussion }\end{array}$ \\
\hline Cerebrolysin & EBEWE & Neurotrophic activity & $\mathrm{AD}$ & $\begin{array}{l}\text { Effect of some doses on } \\
\text { cognition or global } \\
\text { status in randomized } \\
\text { trials }\end{array}$ & $\begin{array}{l}\text { Inconsistent } \\
\text { results }\end{array}$ & $\begin{array}{l}\text { Marketed in many } \\
\text { countries }\end{array}$ \\
\hline Statins & NIA, Pfizer & $\begin{array}{l}\text { Alter cholesterol/amyloid } \\
\text { pathways }\end{array}$ & Normal, AD & $\begin{array}{l}\text { Epidemiology, small } \\
\text { randomized study }\end{array}$ & ADCS, LEADe & $\begin{array}{l}\text { Not actively pursued } \\
\text { for } \mathrm{AD}\end{array}$ \\
\hline Estrogen & NIA & Engage brain estrogen receptors & Normal, AD & $\begin{array}{l}\text { Epidemiology, small } \\
\text { randomized study }\end{array}$ & ADCS, WHI, & $\begin{array}{l}\text { Not actively pursued } \\
\text { for } \mathrm{AD}\end{array}$ \\
\hline NSAIDs & NIA, Merck & $\begin{array}{l}\text { Reduce harmful brain } \\
\text { inflammation }\end{array}$ & $\mathrm{AD}, \mathrm{MCI}$ & Epidemiology & ADCS, Merck & $\begin{array}{l}\text { Not actively pursued } \\
\text { for } \mathrm{AD}\end{array}$ \\
\hline B vitamins & NIA & Reduce homocysteine & $\mathrm{AD}$ & Epidemiology & ADCS & ?MCI \\
\hline HGH, IGF-1 & Merck, others & Normalize HGH-IGF-1 pathways & $\mathrm{AD}$, aging & Epidemiology & MK-677 trial & $\begin{array}{l}\text { Not actively pursued } \\
\text { for } \mathrm{AD}\end{array}$ \\
\hline Lithium & & $\begin{array}{l}\text { Inhibit tau phosphorylation plus } \\
\text { other neuroprotective } \\
\text { mechanisms }\end{array}$ & $\mathrm{AD}$, tauopathies & Preclinical data & Negative RCT & $\begin{array}{l}\text { Not actively pursued } \\
\quad \text { for } \mathrm{AD}\end{array}$ \\
\hline Valproic acid & NIA & $\begin{array}{l}\text { Inhibit tau phosphorylation plus } \\
\text { other neuroprotective } \\
\text { mechanisms }\end{array}$ & $\mathrm{AD}$ & Preclinical data & Negative RCT & $\begin{array}{l}\text { Not actively pursued } \\
\quad \text { for } \mathrm{AD}\end{array}$ \\
\hline
\end{tabular}




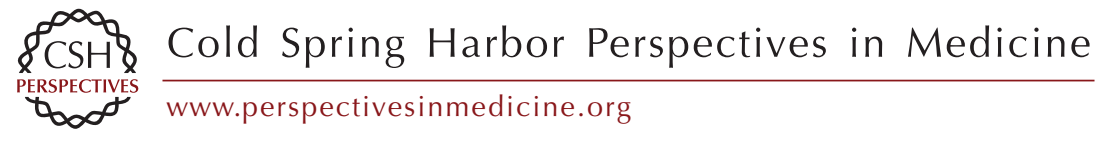

Table 3. Continued

\begin{tabular}{|c|c|c|c|c|c|c|}
\hline Name & Sponsor & $\begin{array}{l}\text { Proposed mechanism or } \\
\text { therapeutic rationale }\end{array}$ & $\begin{array}{c}\text { Target } \\
\text { population }\end{array}$ & Supportive studies & $\begin{array}{l}\text { Nonsupportive } \\
\text { studies/issues }\end{array}$ & Current status \\
\hline Resveratrol & NIA & SIRT-1 & $\begin{array}{l}\mathrm{AD}, \text { normal } \\
\text { aging }\end{array}$ & In vitro, animal studies & $\begin{array}{r}\text { Limited brain } \\
\text { penetration }\end{array}$ & $\mathrm{RCT}$ in $\mathrm{AD}$ beginning \\
\hline Axona & Accera & $\begin{array}{l}\text { Correct ketone body } \\
\text { accumulation }\end{array}$ & $\mathrm{AD}$ & Post-hoc results & Negative RCT & $\begin{array}{l}\text { Marketed as medical } \\
\text { food }\end{array}$ \\
\hline Souvenaid & & $\begin{array}{l}\text { Combination of vitamins to } \\
\text { improve brain cell function }\end{array}$ & $\mathrm{AD}$ & Post-hoc results & Negative RCT & $\begin{array}{l}\text { Marketed as medical } \\
\text { food }\end{array}$ \\
\hline Xaliproden & Sanofi-Aventis & Neuroprotection & $\mathrm{AD}$ & Preclinical data & Negative RCT & $\begin{array}{l}\text { Not actively pursued } \\
\text { for } \mathrm{AD}\end{array}$ \\
\hline Vitamin E & NIA & Antioxidant & $\begin{array}{l}\text { Normal, MCI, } \\
\text { AD }\end{array}$ & Positive $\mathrm{AD}$ trial & Negative MCI trial & $\begin{array}{l}\text { Use limited by } \\
\text { toxicity concerns }\end{array}$ \\
\hline Ginkgo biloba & $\begin{array}{l}\text { NIA, Schwabe, } \\
\text { Ipsen }\end{array}$ & Antioxidant & Normal, AD & $\begin{array}{l}\text { Some randomized trials } \\
\text { in } \mathrm{AD}\end{array}$ & $\begin{array}{l}\text { Negative } \mathrm{AD} \text { and } \\
\text { prevention trials }\end{array}$ & $\begin{array}{l}\text { Over-the-counter } \\
\text { preparations } \\
\text { widely used }\end{array}$ \\
\hline Idebenone & Takeda & Antioxidant & $\mathrm{AD}$ & Preclinical data & Randomized trial & $\begin{array}{l}\text { Not actively pursued } \\
\text { for } \mathrm{AD}\end{array}$ \\
\hline Acetyl-L-carnitine & Sigma Tau & Antioxidant & $\mathrm{AD}$ & Preclinical data & Randomized trials & Two negative RCTs \\
\hline Leuprolide & Curaxis & Gonadotropin pathways & $\mathrm{AD}$ & $\begin{array}{l}\text { Preclinical studies, } \\
\text { epidemiology }\end{array}$ & Randomized trial & Negative RCT \\
\hline NGF gene delivery & NIA Ceregene & Neurotrophic & $\mathrm{AD}$ & Phase I open label study & $\begin{array}{l}\text { Requires } \\
\text { neurosurgical } \\
\text { procedure }\end{array}$ & Phase II in progress \\
\hline
\end{tabular}


demonstrate significant benefit (Harrington et al. 2009; Gold et al. 2010), although post-hoc analysis in an early study suggested benefit in the APOE $\varepsilon 4$ negative subgroup (Risner et al. 2006).

\section{Dimebon (Latrepirdine)}

The course of the dimebon development program includes a number of interesting lessons on the process of bringing new $\mathrm{AD}$ treatments forward (Doody 2009). Dimebon was initially identified by Russian scientists who screened compounds available for clinical use in that country for activity similar to that of the established $\mathrm{AD}$ treatments. They sought a single compound that would combine cholinesterase inhibition with NMDA antagonism. The lead compound to arise from this process was dimebon, a drug used as an antihistamine in Russia until the late 1980s. Following an 8-week open trial in 14 patients (Bachurin et al. 2001), dimebon was licensed by a US company, Medivation, and underwent a 6-month, placebo-controlled Phase II trial, conducted in Russia, in 183 individuals with mild to moderate $\mathrm{AD}$, similar in design to standard trials used with cholinesterase inhibitors and memantine. The results were strikingly positive, with consistent favorable effects on both primary and secondary measures of cognition, function, and behavior (Doody et al. 2008). Further, a blinded extension of the trial to 12 months indicated that benefits of the drug in comparison to placebo appeared to increase with time. This trial suggested that dimebon might have benefits beyond the expectations for a combined cholinesterase inhibitor/NMDA antagonist, and indeed the very limited potency against those targets argued that dimebon must work by a novel mechanism. Activity in vitro against models of mitochondrial toxicity supported that dimebon may be a mitochondrial cytoprotectant. Thus, a drug identified using standard screens appeared to be highly effective based on an unexpected and novel mechanism.

An international Phase III trial was launched to replicate the Russian study findings but including nearly 600 patients, and several other studies were started to explore the efficacy of dimebon added onto donepezil treatment, and to evaluate efficacy in moderate to severe AD. However, the confirmatory study results showed no efficacy, with no apparent explanation for this inconsistency with the Russian Phase II trial. Another Phase III trial, assessing the addition of dimebon to standard therapy for 1 year, continues. Lessons from the dimebon program include the role of serendipity, and the unpredictability and inconsistency in Phase II and smaller sample size AD trials learned from other programs (Schneider 2008b), as well as reasons specific to this drug (Jones 2010).

\section{Statins}

Epidemiological evidence suggests that cholesterol lowering and the use of 3-hydroxy3-methylglutaryl coenzyme A (HMG-CoA) reductase inhibitors ("statins") may modulate the enzymatic processing of amyloid precursor protein and consequently the production of $\beta$-amyloid, and impact the development or progression of AD. Furthermore, cholesterolfed rabbits show increased $A \beta$ in brain, and hypercholesterolemia induced by a high-cholesterol diet results in increased levels of $A \beta$ in the CNS. Statin administration in vitro reduces intra- and extracellular $A \beta$ levels in neuronal cultures. Observational studies of patient records showed a 60-73\% lower prevalence of and markedly reduced risk for $\mathrm{AD}$ in lovastatin (Mevacor)- or pravastatin (Pravachol)-treated patients.

Clinical trials, however, have not supported the use of statins for AD. A randomized, placebo-controlled trial of pravastatin in 5804 subjects with risk factors for vascular disease reported favorable cardiovascular outcomes but no significant effect on cognitive function or disability during an approximately 3-year follow-up period (Trompet et al. 2010). In a randomized, placebo-controlled trial of the effect of simvastatin on cardiovascular outcomes in a subgroup of 5806 patients aged 70 or more years, there was no significant difference in the proportion of patients with cognitive impairment or in the incidence of 
P.S. Aisen et al.

dementia over the average 5-year follow-up period. Two large placebo-controlled trials, one with simvastatin and another with atorvastatin, over 18 months did not show positive effects for the drugs in slowing the clinical decline (McGuinness et al. 2009).

\section{Estrogens}

Preclinical evidence amply demonstrates that estrogens improve cognitive function through cholinergic neuroprotective and neurotrophic effects. Clinical evidence of a possible effect for estrogen replacement therapy (ERT) has included observations of an inverse relationship between ERT and death-certificate diagnoses of dementia, several case-control and cohort studies in which hormonal therapy reducing the risk of $\mathrm{AD}$ were reported, and small clinical reports suggesting that estradiol, estrone, or conjugated equine estrogens enhance cognitive function in AD (Henderson 2006). However, larger studies have not confirmed benefits (Mulnard et al. 2000). Indeed, the large Women's Health Initiative trial revealed an increased risk of dementia and cognitive impairment in women treated with hormone replacement therapy (Shumaker et al. 2003). It is possible but not proven that estrogen treatment in midlife around menopause could be neurotrophic and preventative of the onset of $\mathrm{AD}$, but beyond a few epidemiological studies, evidence is lacking. Particularly in view of growing concerns about adverse health effects, the use of estrogen replacement late in life to prevent or treat MCI or AD cannot be recommended.

\section{ANTI-INFLAMMATORY DRUGS}

There has been enormous interest for more than two decades in the suppression of brain inflammatory activity as an approach to slowing disease progression in AD. Unfortunately, randomized trials of multiple anti-inflammatory regimens, including glucocorticoids (Aisen et al. 2000), nonsteroidal anti-inflammatory drugs (both nonselective and COX-2 selective) (Aisen et al. 2003; Lyketsos et al. 2007), hydroxychloroquine (Van Gool et al. 2001), and dapsone have all failed to demonstrate efficacy.

Curcumin is the active ingredient of curry spicy and is widely used as a food additive in Asian cooking. It has antioxidant properties and has been shown in experimental models to have anti-inflammatory, antioxidant, and anti-amyloid effects (Ringman et al. 2005). There is concern about the brain bioavailability of curcumin, however, and improved formulations are being sought.

\section{INHIBITOR OF THE RECEPTOR FOR ADVANCED GLYCATION ENDPRODUCTS}

The receptor for advanced glycation endproducts (RAGE) is present on neurons, glia, and endothelial cells and is mainly of interest in diabetes and vascular disease in which there is an increased level of various ligands including advanced glycation endproducts that bind to it, effecting pro-inflammatory activity. It is of interest in $\mathrm{AD}$ because of a relationship of $\mathrm{AD}$ to diabetes and because the amyloid peptide is also a RAGE ligand, and this interaction may contribute to brain inflammation and accumulation of amyloid. The latter effect might result in increased CNS A $\beta$ as well as inflammatory effects in $\mathrm{AD}$ patients. Thus RAGE blockers could be therapeutically useful in diabetes and AD. After a small Phase II trial indicated the tolerability of an oral inhibitor of RAGE in AD (Sabbagh et al. 2010), an 18-month trial was launched, with results expected soon.

\section{NGF GENE DELIVERY}

The most important component of the brain's capacity to protect the function of cholinergic neurons is nerve growth factor (NGF). Early attempts to utilize NGF to protect these neurons in $\mathrm{AD}$ were unsuccessful because of toxicity; NGF delivered into the CSF stimulates ependymal cell proliferation with resulting toxicity such as pain. The advance of gene delivery methods has led to a resurgence of interest in NGF; primate studies showed that NGF gene delivery to the cholinergic nucleus basalis 
resulted in long-term gene expression with neurotrophic effects.

A Phase I study of stereotactic NGF gene delivery using transformed fibroblasts derived from skin biopsies showed that NGF expression could be induced in nucleus basalis cells in humans with $\mathrm{AD}$, with some evidence of increased brain function by FDG-PET scanning (Tuszynski et al. 2005). An NIA-funded, randomized, sham-surgery controlled Phase II trial of NGF gene delivery using a viral vector is currently in progress.

\section{SIRTUINS AND RESVERATROL}

Modifications of DNA and post-translational nuclear proteins may produce lasting alterations in chromatin, alter patterns of gene expression, and may affect neuroplasticity. Dysregulation of such epigenetic mechanisms may affect aging brain and cognitive impairment. Histone deacetylation (HDAC) may contribute to pathologic transcriptional aberrations in brain disease and HDAC activation may have therapeutic potential. Sirtuins, a family of histone deacetylation compounds, may be important to epigenetic mechanisms, and may be involved in the cellular protection afforded by calorie restriction (Gan 2007). Targeting sirtuins represents a new approach to neurodegenerative disorders.

There is great interest in the potential benefits of polyphenolic compounds derived from various fruits, vegetables, and plants. Polyphenols are potent antioxidants in vitro, and have been studied as potential therapeutics in cardiovascular disease and cancer, in part based on epidemiological evidence. Similarly, there is interest in polyphenols to reduce the adverse effects of aging on the function of organs including brain; neuroprotective effects have been shown in vitro.

Resveratrol is a polyphenol particularly abundant in the skin of red grapes; it has been suggested that this may in part explain epidemiological links between red wine consumption and reduced risk of AD (Vingtdeux et al. 2008). In vivo data have clearly shown the neuroprotective properties of the naturally occurring polyphenol resveratrol in rodent models for stress and diseases. Furthermore, recent work in cell cultures and animal models has shed light on the molecular mechanisms potentially involved in the beneficial effects of resveratrol intake against the neurodegenerative process in $\mathrm{AD}$. Laboratory studies indicate that resveratrol is an activator of sirtuins. Resveratrol and other sirtuin activators increase longevity and slow brain atrophy in a number of species including nonhuman primates.

Although brain penetration of resveratrol is limited, some studies suggest that it may have a peripheral action that reduces brain amyloid accumulation. A NIA-funded study of the impact of resveratrol on biomarkers of $\mathrm{AD}$ will be initiated in early 2011.

\section{SUMMARY}

AChE-Is and the NMDA receptor antagonist memantine are FDA approved for treatment of AD. Transmitter based therapies represent the only validated treatments of AD. Deficits in transmitters not addressed by current therapies suggest that manipulation of these transmitter systems are worthy targets for cognitive enhancement. A plethora of metabolic, intracellular, and neuroprotective approaches populate this potential therapeutic space and represent new and emerging treatments for AD. Particularly for drug development programs aiming to slow progression of underlying pathobiological mechanisms, clinical impact is likely to be greatest if treatment is initiated early, prior to the onset of dementia or even in the presymptomatic stage of the disease process.

\section{ACKNOWLEDGMENTS}

Dr. Aisen serves on a scientific advisory board for NeuroPhage and serves as a consultant to Elan Corporation, Wyeth, Eisai Inc., ScheringPlough Corp., Bristol-Myers Squibb, Eli Lilly and Company, NeuroPhage, Merck \& Co., Roche, Amgen, Genentech, Inc., Abbott, Pfizer Inc, Novartis, Bayer, and Medivation, Inc. He receives research support from Pfizer Inc, Baxter International Inc., and the NIH [NIA 
P.S. Aisen et al.

U01-AG10483 (PI), NIA U01-AG024904

(Coordinating Center Director), NIA R01AG030048 (PI), and R01-AG16381 (Co-I)]; and he has received stock options from Medivation, Inc. and NeuroPhage.

Dr. Cummings has provided consultation to Abbott, Acadia, ADAMAS, Astellas, Baxter, Bayer, Bristol-Meyers Squibb, Eisai, EnVivo, Forest, Genentech, GlaxoSmithKline, Janssen, Lilly, Lundbeck, Medivation, Merck, Neurokos, Novartis, Pfizer, Prana, QR Pharma, reMYND, Signum, Sonexa, Takeda, and Toyama pharmaceutical companies. He has stock options in ADAMAS, Prana, Sonexa, and Neurokos. Dr. Cummings owns the copyright of the Neuropsychiatric Inventory.

Dr. Schneider reports being an editor on the Cochrane Collaboration Dementia and Cognitive Improvement Group, which oversees systematic reviews of drugs for cognitive impairment and dementia. He received a grant from the Alzheimer's Association for a registry for dementia and cognitive impairment trials; he is also in receipt of grant or research support from Baxter, Elan Pharmaceuticals, Johnson \& Johnson, Eli Lilly, Myriad, Novartis, and Pfizer. He has served as a consultant for or received consulting fees from Abbott Laboratories, AC Immune, Allergan, Allon, Alzheimer Drug Discovery Foundation, AstraZeneca, Bristol-Myers Squibb, Elan, Eli Lilly, Exonhit, Forest, GlaxoSmithKline, Ipsen Pharmaceuticals, Johnson \& Johnson, Lundbeck, Myriad, Medavante, Medivation, Merck, Merz, Novartis, Pfizer, Roche, Sanofi-Aventis, Schering-Plough, Schwabe, Toyama, and Transition Therapeutics.

\section{REFERENCES}

AD2000 Collaborative Group. 2004. Long-term donepezil treatment in 565 patients with Alzheimer's disease (AD2000): Randomised double-blind trial. Lancet 363: 2105-2115.

Aisen PS, Davis KL, Berg JD, Schafer K, Campbell K, Thomas RG, Weiner MF, Farlow MR, Sano M, Grundman $\mathrm{M}$, et al. 2000. A randomized controlled trial of prednisone in Alzheimer's disease. Alzheimer's Disease Cooperative Study. Neurology 54: 588-593.

Aisen PS, Schafer KA, Grundman M, Pfeiffer E, Sano M, Davis KL, Farlow MR, Jin S, Thomas RG, Thal LJ 2003. Effects of rofecoxib or naproxen vs placebo on
Alzheimer disease progression: A randomized controlled trial. J Am Med Assoc 289: 2819-2826.

Aisen PS, Saumier D, Briand R, Laurin J, Gervais F, Tremblay P, Garceau D. 2006. A Phase II study targeting amyloidbeta with 3APS in mild-to-moderate Alzheimer disease. Neurology 67: 1757-1763.

Aisen PS, Schneider LS, Sano M, Diaz-Arrastia R, van Dyck $\mathrm{CH}$, Weiner MF, Bottiglieri T, Jin S, Stokes KT, Thomas RG, et al. 2008. High-dose B vitamin supplementation and cognitive decline in Alzheimer disease: A randomized controlled trial [see comment]. J Am Med Assoc 300: $1774-1783$.

Albert MS, Dekosky ST, Dickson D, Dubois B, Feldman HH, Fox NC, Gamst A, Holtzman DM, Jagust WJ, Petersen RC, et al. 2011. The diagnosis of mild cognitive impairment due to Alzheimer's disease: Recommendations from the National Institute on Aging-Alzheimer's Association workgroups on diagnostic guidelines for $\mathrm{Alz}$ heimer's disease. Alzheimers Dement 7: 270-279.

Bachurin S, Bukatina E, Lermontova N, Tkachenko S, Afanasiev A, Grigoriev V, Grigorieva I, Ivanov YU, Sablin S, Zefirov N. 2001. Antihistamine agent dimebon as a novel neuroprotector and a cognition enhancer. Ann NY Acad Sci 939: 425-435.

Bakchine S, Loft H. 2008. Memantine treatment in patients with mild to moderate Alzheimer's disease: Results of a randomised, double-blind, placebo-controlled 6-month study. J Alzheimers Dis 13: 97-107.

Ballard C, Waite J. 2006. The effectiveness of atypical antipsychotics for the treatment of aggression and psychosis in Alzheimer's disease. Cochrane Database Syst Rev CD003476.

Ballard C, Hanney ML, Theodoulou M, Douglas S, McShane R, Kossakowski K, Gill R, Juszczak E, Yu LM, Jacoby R. 2009. The dementia antipsychotic withdrawal trial (DART-AD): Long-term follow-up of a randomised placebo-controlled trial. Lancet Neurol 8: 151-157.

Birks J. 2006. Cholinesterase inhibitors for Alzheimer's disease. Cochrane Database Syst Rev CD005593.

Birks J, Grimley Evans J. 2009. Ginkgo biloba for cognitive impairment and dementia. John Wiley, Chichester, UK.

Black S, Roman GC, Geldmacher DS, Salloway S, Hecker J, Burns A, Perdomo C, Kumar D, Pratt R. 2003. Efficacy and tolerability of donepezil in vascular dementia: Positive results of a 24-week, multicenter, international, randomized, placebo-controlled clinical trial. Stroke 34: 2323-2330.

Craft S. 2007. Insulin resistance and Alzheimer's disease pathogenesis: Potential mechanisms and implications for treatment. Curr Alzheimer Res 4: 147-152.

Craft S, Baker LD, Montine TJ, Minoshima S, Watson GS, Claxton A, Arbuckle M, Callaghan M, Tsai E, Plymate $\mathrm{SR}$, et al. 2011. Intranasal insulin therapy for $\mathrm{Alz}$ heimer disease and amnestic mild cognitive impairment. Arch Neurol doi: 10.1001/archneurol.2011.233.

Cummings J. 2003. Neuropsychiatry of Alzheimer's disease and related dementias. Martin Dunitz, London.

Cummings JL, Mega M, Gray K, Rosenberg-Thompson S, Carusi DA, Gornbein J. 1994. The Neuropsychiatric Inventory: Comprehensive assessment of psychopathology in dementia. Neurology 44: 2308-2314. 
DeKosky ST, Williamson JD, Fitzpatrick AL, Kronmal RA, Ives DG, Saxton JA, Lopez OL, Burke G, Carlson MC, Fried LP, et al. 2008. Ginkgo biloba for prevention of dementia: A randomized controlled trial. J Am Med Assoc 300: $2253-2262$.

Dodge HH, Zitzelberger T, Oken BS, Howieson D, Kaye J. 2008. A randomized placebo-controlled trial of Ginkgo biloba for the prevention of cognitive decline. Neurology 70: $1809-1817$.

Doody RS. 2009. Dimebon as a potential therapy for Alzheimer's disease. CNS Spectr 14: 16-18.

Doody RS, Gavrilova SI, Sano M, Thomas RG, Aisen PS, Bachurin SO, Seely L, Hung D. 2008. Effect of dimebon on cognition, activities of daily living, behaviour, and global function in patients with mild-to-moderate Alzheimer's disease: A randomised, double-blind, placebo-controlled study. Lancet 372: 207-215.

Emre M, Aarsland D, Albanese A, Byrne EJ, Deuschl G, De Deyn PP, Durif F, Kulisevsky J, van Laar T, Lees A, et al. 2004. Rivastigmine for dementia associated with Parkinson's disease. N Engl J Med 351: 2509-2518.

Erkinjuntti T, Kurz A, Gauthier S, Bullock R, Lilienfeld S, Damaraju CV. 2002. Efficacy of galantamine in probable vascular dementia and Alzheimer's disease combined with cerebrovascular disease: A randomised trial. Lancet 359: 1283-1290.

Folstein MF, Folstein SE, McHugh PR. 1975. "Mini-mental state." A practical method for grading the cognitive state of patients for the clinician. J Psychiatr Res 12: 189-198.

Frankiewicz T, Parsons CG. 1999. Memantine restores long term potentiation impaired by tonic N-methylD-aspartate (NMDA) receptor activation following reduction of $\mathrm{Mg}^{2+}$ in hippocampal slices. Neuropharmacology 38: 1253-1259.

Galasko D, Bennett D, Sano M, Ernesto C, Thomas R, Grundman M, Ferris S. 1997. An inventory to assess activities of daily living for clinical trials in Alzheimer's disease. The Alzheimer's Disease Cooperative Study. Alzheimer Dis Assoc Disord 11 (Suppl 2): S33-S39.

Gan L. 2007. Therapeutic potential of sirtuin-activating compounds in Alzheimer's disease. Drug News Perspect 20: $233-239$.

Geldmacher DS, Frolich L, Doody RS, Erkinjuntti T, Vellas B, Jones RW, Banerjee S, Lin P, Sano M. 2006. Realistic expectations for treatment success in Alzheimer's disease. J Nutr Health Aging 10: 417-429.

Geldmacher DS, Fritsch T, McClendon MJ, Landreth G. 2011. A randomized pilot clinical trial of the safety of pioglitazone in treatment of patients with Alzheimer disease. Arch Neurol 68: 45-50.

Gelinas I, Gauthier L, McIntyre M, Gauthier S. 1999. Development of a functional measure for persons with Alzheimer's disease: The disability assessment for dementia. Am J Occup Ther 53: 471-481.

Gold M, Alderton C, Zvartau-Hind M, Egginton S, Saunders $A M$, Irizarry $M$, Craft $S$, Landreth $G$, Linnamägi Ü, Sawchak S. 2010. Rosiglitazone monotherapy in mild-to-moderate Alzheimer's disease: Results from a randomized, double-blind, placebo-controlled Phase III study. Dement Geriatr Cogn Disord 30: 131-146.

Harrington C, Sawchak S, Chiang C, Davies J, Saunders A, Irizarry $\mathrm{M}$, Zvartau-Hind $\mathrm{M}$, van Dyck C, Gold $\mathrm{M}$.
2009. Effects of rosiglitazone-extended release as adjunctive therapy to acetylcholinesterase inhibitors over 48 weeks on cognition in apoe4-stratified subjects with mild-to-moderate Alzheimer's disease. Alzheimers Dement 5: e17-e18.

Henderson VW. 2006. Estrogen-containing hormone therapy and Alzheimer's disease risk: Understanding discrepant inferences from observational and experimental research. Neuroscience 138: 1031-1039.

Henderson S, Vogel J, Barr L, Garvin F, Jones J, Costantini L. 2009. Study of the ketogenic agent AC-1202 in mild to moderate Alzheimer's disease: A randomized, doubleblind, placebo-controlled, multicenter trial. Nutr Metab 6: 31 .

Herrmann N, Lanctot KL, Rothenburg LS, Eryavec G. 2007. A placebo-controlled trial of valproate for agitation and aggression in Alzheimer's disease. Dement Geriatr Cogn Disord 23: 116-119.

Holmes C, Wilkinson D, Dean C, Vethanayagam S, Olivieri S, Langley A, Pandita-Gunawardena ND, Hogg F, Clare C, Damms J. 2004. The efficacy of donepezil in the treatment of neuropsychiatric symptoms in Alzheimer disease. Neurology 63: 214-219.

Jack CR Jr, Petersen RC, Grundman M, Jin S, Gamst A, Ward CP, Sencakova D, Doody RS, Thal LJ. 2008. Longitudinal MRI findings from the vitamin $\mathrm{E}$ and donepezil treatment study for MCI. Neurobiol Aging 29: $1285-1295$.

Jelic V, Kivipelto M, Winblad B. 2006. Clinical trials in mild cognitive impairment: Lessons for the future. J Neurol Neurosurg Psychiatry 77: 429-438.

Jicha GA, Parisi JE, Dickson DW, Johnson K, Cha R, Ivnik RJ, Tangalos EG, Boeve BF, Knopman DS, Braak H, et al. 2006. Neuropathologic outcome of mild cognitive impairment following progression to clinical dementia. Arch Neurol 63: 674-681.

Jones R. 2010. Dimebon disappointment. Alzheimers Res Ther 2: 25 .

Kales HC, Valenstein M, Kim HM, McCarthy JF, Ganoczy D, Cunningham F, Blow FC. 2007. Mortality risk in patients with dementia treated with antipsychotics versus other psychiatric medications. Am J Psychiatry 164: $1568-1576$.

Kavirajan H, Schneider LS. 2007. Efficacy and adverse effects of cholinesterase inhibitors and memantine in vascular dementia: A meta-analysis of randomised controlled trials [see comment]. Lancet Neurol 6: 782-792.

Kimura M, Akasofu S, Ogura H, Sawada K. 2005. Protective effect of donepezil against $A \beta(1-40)$ neurotoxicity in rat septal neurons. Brain Res 1047: 72-84.

Krishnan KR, Charles HC, Doraiswamy PM, Mintzer J, Weisler R, Yu X, Perdomo C, Ieni JR, Rogers S. 2003. Randomized, placebo-controlled trial of the effects of donepezil on neuronal markers and hippocampal volumes in Alzheimer's disease. Am J Psychiatry 160: 2003-2011.

Lopez OL, Becker JT, Wahed AS, Saxton J, Sweet RA, Wolk DA, Klunk W, Dekosky ST. 2009. Long-term effects of the concomitant use of memantine with cholinesterase inhibition in Alzheimer disease. J Neurol Neurosurg Psychiatry 80: 600-607. 
P.S. Aisen et al.

Lyketsos CG, Sheppard JM, Steele CD, Kopunek S, Steinberg M, Baker AS, Brandt J, Rabins PV. 2000. Randomized, placebo-controlled, double-blind clinical trial of sertraline in the treatment of depression complicating Alzheimer's disease: Initial results from the Depression in Alzheimer's Disease study. Am J Psychiatry 157: $1686-1689$.

Lyketsos CG, Breitner JC, Green RC, Martin BK, Meinert C, Piantadosi S, Sabbagh M. 2007. Naproxen and celecoxib do not prevent $\mathrm{AD}$ in early results from a randomized controlled trial. Neurology 68: 1800-1808.

Martinez-Coria H, Green KN, Billings LM, Kitazawa M, Albrecht M, Rammes G, Parsons CG, Gupta S, Banerjee P, LaFerla FM. 2010. Memantine improves cognition and reduces Alzheimer's-like neuropathology in transgenic mice. Am J Pathol 176: 870-880.

McCarney R, Fisher P, Iliffe S, van Haselen R, Griffin M, van der Meulen J, Warner J. 2008. Ginkgo biloba for mild to moderate dementia in a community setting: A pragmatic, randomised, parallel-group, double-blind, placebocontrolled trial. Int J Geriatr Psychiatry 23: 1222-1230.

McGuinness B, Craig D, Bullock R, Passmore P. 2009. Statins for the prevention of dementia. Cochrane Database Syst Rev CD003160.

McKeith I, Del Ser T, Spano P, Emre M, Wesnes K, Anand R, Cicin-Sain A, Ferrara R, Spiegel R. 2000. Efficacy of rivastigmine in dementia with Lewy bodies: A randomised, double-blind, placebo-controlled international study. Lancet 356: 2031-2036.

Mulnard RA, Cotman CW, Kawas C, van Dyck CH, Sano M, Doody R, Koss E, Pfeiffer E, Jin S, Gamst A, et al. 2000 Estrogen replacement therapy for treatment of mild to moderate Alzheimer disease: A randomized controlled trial. Alzheimer's Disease Cooperative Study. J Am Med Assoc 283: 1007-1015.

Okamura N, Funaki Y, Tashiro M, Kato M, Ishikawa Y, Maruyama M, Ishikawa H, Meguro K, Iwata R, Yanai K. 2008. In vivo visualization of donepezil binding in the brain of patients with Alzheimer's disease. Br J Clin Pharmacol 65: 472-479.

Olin JT, Katz IR, Meyers BS, Schneider LS, Lebowitz BD. 2002. Provisional diagnostic criteria for depression of Alzheimer disease: Rationale and background. Am J Geriatr Psychiatry 10: 129-141.

Peskind ER, Potkin SG, Pomara N, Ott BR, Graham SM, Olin JT, McDonald S. 2006. Memantine treatment in mild to moderate Alzheimer disease: A 24-week randomized, controlled trial. Am J Geriatr Psychiatry 14: 704-715.

Petersen RC, Doody R, Kurz A, Mohs RC, Morris JC, Rabins PV, Ritchie K, Rossor M, Thal L, Winblad B. 2001. Current concepts in mild cognitive impairment. Arch Neurol 58: 1985-1992.

Petersen RC, Thomas RG, Grundman M, Bennett D, Doody R, Ferris S, Galasko D, Jin S, Kaye J, Levey A, et al. 2005. Vitamin $\mathrm{E}$ and donepezil for the treatment of mild cognitive impairment [see comment]. New Engl J Med 352: 2379-2388.

Porsteinsson AP, Grossberg GT, Mintzer J, Olin JT. 2008. Memantine treatment in patients with mild to moderate Alzheimer's disease already receiving a cholinesterase inhibitor: A randomized, double-blind, placebocontrolled trial. Curr Alzheimer Res 5: 83-89.

Quinn JF, Raman R, Thomas RG, Yurko-Mauro K, Nelson EB, Van Dyck C, Galvin JE, Emond J, Jack CR Jr, Weiner M, et al. 2010. Docosahexaenoic acid supplementation and cognitive decline in Alzheimer disease: A randomized trial. J Am Med Assoc 304: 1903-1911.

Rafii MS, Walsh S, Little JT, Behan KE, Reynolds B, Ward CJ, Thomas R, Aisen PS. 2011. A phase II trial of huperzine A in mild to moderate Alzheimer disease. Neurology 76: 1389-1394.

Reisberg B, Doody R, Stoffler A, Schmitt F, Ferris S, Mobius HJ. 2003a. Memantine in moderate-to-severe Alzheimer's disease. N Engl J Med 348: 1333-1341.

Reisberg B, Doody R, Stoffler A, Schmitt F, Ferris S, Mobius HJ, Memantine Study Group. 2003b. Memantine in moderate-to-severe Alzheimer's disease [see comment]. New Engl J Med 348: 1333-1341.

Ringman JM, Frautschy SA, Cole GM, Masterman DL, Cummings JL. 2005. A potential role of the curry spice curcumin in Alzheimer's disease. Curr Alzheimer Res 2: $131-136$.

Risner ME, Saunders AM, Altman JF, Ormandy GC, Craft S, Foley IM, Zvartau-Hind ME, Hosford DA, Roses AD. 2006. Efficacy of rosiglitazone in a genetically defined population with mild-to-moderate Alzheimer's disease. Pharmacogenomics J 6: 246-254.

Rosen WG, Mohs RC, Davis KL. 1984. A new rating scale for Alzheimer's disease. Am J Psychiatry 141: 1356-1364.

Rosenberg PB, Drye LT, Martin BK, Frangakis C, Mintzer JE, Weintraub D, Porsteinsson AP, Schneider LS, Rabins PV, Munro CA, et al. 2010. Sertraline for the treatment of depression in Alzheimer disease. Am J Geriatr Psychiatry 18: $136-145$.

Rountree SD, Chan W, Pavlik VN, Darby EJ, Siddiqui S, Doody RS. 2009. Persistent treatment with cholinesterase inhibitors and/or memantine slows clinical progression of Alzheimer disease. Alzheimers Res Ther 1: 7.

Sabbagh MN, Agro A, Bell J, Aisen PS, Schweizer E, Galasko D. 2010. PF-04494700, an oral inhibitor of receptor for advanced glycation end products (RAGE), in Alzheimer disease. Alzheimer Dis Assoc Disord 25: 206-212.

Sano M, Ernesto C, Thomas RG, Klauber MR, Schafer K, Grundman M, Woodbury P, Growdon J, Cotman CW, Pfeiffer E, et al. 1997. A controlled trial of selegiline, alpha-tocopherol, or both as treatment for Alzheimer's disease. The Alzheimer's Disease Cooperative Study [see comment]. New Engl J Med 336: 1216-1222.

Sato T, Hanyu H, Hirao K, Kanetaka H, Sakurai H, Iwamoto T. 2011. Efficacy of PPAR-gamma agonist pioglitazone in mild Alzheimer disease. Neurobiol Aging 32: 1626-1633.

Scheltens P, Kamphuis PJGH, Verhey FRJ, Olde Rikkert MGM, Wurtman RJ, Wilkinson D, Twisk JWR, Kurz A. 2010. Efficacy of a medical food in mild Alzheimer's disease: A randomized, controlled trial. Alzheimers Dement 6: 1-10; e11.

Schmitt FA, Ashford W, Ernesto C, Saxton J, Schneider LS, Clark CM, Ferris SH, Mackell JA, Schafer K, Thal LJ. 1997. The severe impairment battery: Concurrent validity and the assessment of longitudinal change in Alzheimer's disease. The Alzheimer's Disease Cooperative Study. Alzheimer Dis Assoc Disord 11 (Suppl 2): S51-S56. 
Schneider LS. 2008a. Ginkgo biloba extract and preventing Alzheimer disease [comment]. J Am Med Assoc 300: 2306-2308.

Schneider LS. 2008b. Issues in design and conduct of clinical trials for cognitive-enhancing drugs. In Animal and translational models for CNS drug discovery (ed. Robert AM, Franco B), pp. 21-76. Academic, San Diego.

Schneider LS, Sano M. 2009. Current Alzheimer's disease clinical trials: Methods and placebo outcomes. Alzheimers Dement 5: 388-397.

Schneider LS, Olin JT, Doody RS, Clark CM, Morris JC Reisberg B, Schmitt FA, Grundman M, Thomas RG, Ferris SH. 1997. Validity and reliability of the Alzheimer's Disease Cooperative Study — clinical global impression of change. The Alzheimer's Disease Cooperative Study. Alzheimer Dis Assoc Disord 11 (Suppl 2): S22-S32.

Schneider LS, DeKosky ST, Farlow MR, Tariot PN, Hoerr R, Kieser M. 2005. A randomized, double-blind, placebocontrolled trial of two doses of Ginkgo biloba extract in dementia of the Alzheimer's type [see comment]. Curr Alzheimer Res 2: 541-551.

Schneider LS, Dagerman K, Insel PS. 2006. Efficacy and adverse effects of atypical antipsychotics for dementia: Meta-analysis of randomized, placebo-controlled trials. Am J Geriatr Psychiatry 14: 191-210.

Schneider LS, Insel PS, Weiner MW, for the Alzheimer's Disease Neuroimaging Initiative. 2011. Treatment with cholinesterase inhibitors and memantine of patients in the Alzheimer's Disease Neuroimaging Initiative. Arch Neurol 68: 58-66.

Shumaker SA, Legault C, Rapp SR, Thal L, Wallace RB, Ockene JK, Hendrix SL, Jones BN 3rd, Assaf AR, Jackson RD, et al. 2003. Estrogen plus progestin and the incidence of dementia and mild cognitive impairment in postmenopausal women: The Women's Health Initiative Memory Study: A randomized controlled trial. J Am Med Assoc 289: $2651-2662$.

Smith AD, Smith SM, de Jager CA, Whitbread P, Johnston C, Agacinski G, Oulhaj A, Bradley KM, Jacoby R, Refsum H. 2010. Homocysteine-lowering by $B$ vitamins slows the rate of accelerated brain atrophy in mild cognitive impairment: A randomized controlled trial. PLoS One 5: e12244.

Tariot PN, Erb R, Podgorski CA, Cox C, Patel S, Jakimovich L, Irvine C. 1998. Efficacy and tolerability of carbamazepine for agitation and aggression in dementia. Am J Psychiatry 155: 54-61.

Tariot PN, Farlow MR, Grossberg GT, Graham SM, McDonald S, Gergel I. 2004. Memantine treatment in patients with moderate to severe Alzheimer disease already receiving donepezil: A randomized controlled trial. J Am Med Assoc 291: 317-324.
Tariot PN, Raman R, Jakimovich L, Schneider L, Porsteinsson A, Thomas R, Mintzer J, Brenner R, Schafer K, Thal L. 2005. Divalproex sodium in nursing home residents with possible or probable Alzheimer Disease complicated by agitation: A randomized, controlled trial. Am J Geriatr Psychiatry 13: 942-949.

Trompet S, van Vliet P, de Craen AJ, Jolles J, Buckley BM, Murphy MB, Ford I, Macfarlane PW, Sattar N, Packard CJ, et al. 2010. Pravastatin and cognitive function in the elderly. Results of the PROSPER study. J Neurol 257: 85-90.

Tuszynski MH, Thal L, Pay M, Salmon DP, HS UBakay R, Patel P, Blesch A, Vahlsing HL, Ho G, et al. 2005. A phase 1 clinical trial of nerve growth factor gene therapy for $\mathrm{Alz}$ heimer disease. Nat Med 11: 551-555.

van Dyck CH, Tariot PN, Meyers B, Resnick ME. 2007. A 24-week randomized, controlled trial of memantine in patients with moderate-to-severe Alzheimer disease. Alzheimer Dis Assoc Disord 21: 136-143.

Van Gool WA, Weinstein HC, Scheltens P, Walstra GJ. 2001. Effect of hydroxychloroquine on progression of dementia in early Alzheimer's disease: An 18-month randomised, double-blind, placebo-controlled study. Lancet 358: 455-460.

Vingtdeux V, Dreses-Werringloer U, Zhao H, Davies P, Marambaud P. 2008. Therapeutic potential of resveratrol in Alzheimer's disease. BMC Neurosci 9 (Suppl 2): S6.

Weintraub D, Rosenberg PB, Drye LT, Martin BK, Frangakis C, Mintzer JE, Porsteinsson AP, Schneider LS, Rabins PV, Munro CA, et al. 2010. Sertraline for the treatment of depression in Alzheimer disease: Week-24 outcomes. Am J Geriatr Psychiatry 18: 332-340.

Whitehead A, Perdomo C, Pratt RD, Birks J, Wilcock GK, Evans JG. 2004. Donepezil for the symptomatic treatment of patients with mild to moderate Alzheimer's disease: A meta-analysis of individual patient data from randomised controlled trials. Int J Geriatr Psychiatry 19: 624-633.

Wimo A, Winblad B. 2003. Resource utilisation in dementia: RUD Lite. Brain Aging 3: 48-59.

Winblad B, Poritis N. 1999. Memantine in severe dementia: results of the 9M-Best Study (benefit and efficacy in severely demented patients during treatment with memantine). Int J Geriatr Psychiatry 14: 135-146.

Winblad B, Engedal K, Soininen H, Verhey F, Waldemar G, Wimo A, Wetterholm AL, Zhang R, Haglund A, Subbiah P. 2001. A 1-year, randomized, placebo-controlled study of donepezil in patients with mild to moderate AD. Neurology 57: 489-495. 


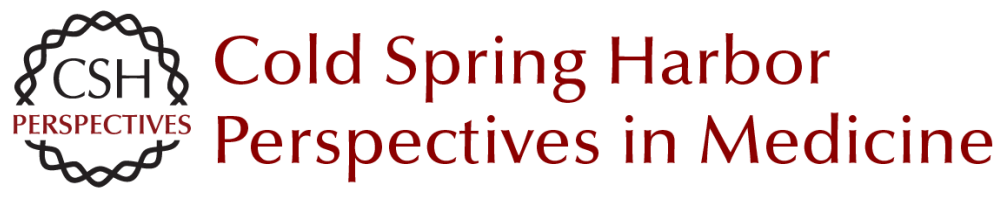

\title{
Symptomatic and Nonamyloid/Tau Based Pharmacologic Treatment for Alzheimer Disease
}

\author{
Paul S. Aisen, Jeffrey Cummings and Lon S. Schneider
}

Cold Spring Harb Perspect Med 2012; doi: 10.1101/cshperspect.a006395 originally published online November 30, 2011

Subject Collection The Biology of Alzheimer Disease

Animal Models of Alzheimer Disease

Frank M. LaFerla and Kim N. Green

Neurovascular Dysfunction and Faulty Amyloid $\beta$ -Peptide Clearance in Alzheimer Disease Abhay P. Sagare, Robert D. Bell and Berislav V. Zlokovic

Treatment Strategies Targeting Amyloid $\beta$-Protein Dale Schenk, Guriqbal S. Basi and Menelas N. Pangalos

The Ubiquitin-Proteasome System and the Autophagic-Lysosomal System in Alzheimer Disease

Yasuo Ihara, Maho Morishima-Kawashima and Ralph Nixon

Neurotoxicity of Amyloid $\beta$-Protein: Synaptic and Network Dysfunction Lennart Mucke and Dennis J. Selkoe

Proteolytic Degradation of Amyloid $\beta$-Protein Takaomi Saido and Malcolm A. Leissring

Brain Imaging in Alzheimer Disease Keith A. Johnson, Nick C. Fox, Reisa A. Sperling, et al.

Symptomatic and Nonamyloid/Tau Based Pharmacologic Treatment for Alzheimer Disease Paul S. Aisen, Jeffrey Cummings and Lon S. Schneider
Alzheimer Disease in 2020

David M. Holtzman, Eckhard Mandelkow and Dennis J. Selkoe

The Genetics of Alzheimer Disease Rudolph E. Tanzi

Fluid Biomarkers in Alzheimer Disease

Kaj Blennow, Henrik Zetterberg and Anne M. Fagan

Epidemiology of Alzheimer Disease

Richard Mayeux and Yaakov Stern

\begin{abstract}
Biochemistry and Cell Biology of Tau Protein in Neurofibrillary Degeneration

Eva-Maria Mandelkow and Eckhard Mandelkow

Biochemistry of Amyloid $\beta$-Protein and Amyloid

Deposits in Alzheimer Disease

Colin L. Masters and Dennis J. Selkoe
\end{abstract}

The Neuropsychological Profile of Alzheimer

Disease

Sandra Weintraub, Alissa H. Wicklund and David P.

Salmon

Apolipoprotein E and Apolipoprotein E Receptors: Normal Biology and Roles in Alzheimer Disease David M. Holtzman, Joachim Herz and Guojun Bu

For additional articles in this collection, see http://perspectivesinmedicine.cshlp.org/cgi/collection/ 